\title{
Digitodesmium recurvum, a new species of chirosporous hyphomycete from Hong Kong
}

\author{
Wai-Hong $\mathrm{Ho}^{1}$ \\ Kevin D. Hyde \\ I. John Hodgkiss \\ Centre for Research in Fungal Diversity, Department of \\ Ecology and Biodiversity, The University of Hong \\ Kong, Pokfulam Road, Hong Kong
}

\begin{abstract}
Digitodesmium recurvum sp. nov., recorded from freshwater habitats in Hong Kong, is described and illustrated. Digitodesmium recurvum is characterized by chiroid, olivaceous brown, euseptate conidia composed of 4-6 apically recurved arms. Characteristics of the conidia of the two known species of Digitodesmium are summarized, and a comparison with other similar species is also provided.
\end{abstract}

Key Words: aquatic fungi, lignicolous fungi, systematics, taxonomy

In a continuing study of freshwater mycota in the tropics (Ho et al 1997, 1999b, c, Goh et al 1998b, Hyde et al 1998), an undescribed dematiaceous hyphomycete was found on wood baits of Machilus velutina and on other naturally occurring wood submerged in a small stream in Hong Kong. This fungus produces chiroid conidia in sporodochia. Critical examination of the morphological characters suggested placement in the genus Digitodesmium P. M. Kirk.

The genus Digitodesmium was erected by Kirk (1981) to accommodate a single species, Dig. elegans P. M. Kirk, found on rotten wood of Fagus sylvatica, Quercus roboris and Taxus baccata(?) from Surrey, England. Digitodesmium elegans is characterized by the presence of punctiform, sporodochial conidiomata and semi-macronematous, mononematous conidiophores. The conidiogenous cells are discrete, monoblastic, and do not proliferate; the conidia are holoblastic, composed of a truncate basal cell on which (2-) 3-4(-6) arms are formed in different planes. The arms are straight, cylindrical, vertical, appressed to each other or slightly divergent and euseptate, and the conidia secede schizolytically (Kirk 1981). Digitodesmium remains monotypic and its teleomorph is presently unknown. The species of Digitodesmium col-

Accepted for publication May 10, 1999.

${ }^{1}$ Email: whho@graduate.hku.hk lected in Hong Kong is significantly different from the type species and is therefore described as new.

Digitodesmium recurvum W. H. Ho, K. D. Hyde et I. J. Hodgkiss, sp. nov. $\quad$ FIGS. 1-9

Conidiomata sporodochia, sparsa, punctiformia, pulvinata, atrobrunnea vel atra, 100-300 $\mu \mathrm{m}$ diameter. Mycelium in substrato plerumque immersum, ex hyphis brunneis, laevibus, tenuitunicatis, septatis, ramosis compositum. Conidiophora semi-macronematosa, mononematosa, pallide brunnea, laevia, tenuitunicata, non-ramosa, cylindrica, flexuosa, 6-14 $\times 3-5 \mu \mathrm{m}$. Cellulae conidiogene monoblasticae, in conidiophoris incorporatae, terminales, determinatae, pallide brunneae, laeves, tenuitunicatae. Conidia acrogena, holoblastica, solitaria, pallide brunnea, cheiroidea, 30-45 × 12$21 \mu \mathrm{m}$, euseptata, cum 4-7(-8) rami praedita, verticalia; cellula basilaris 3.5-6 $\times 3.5-5 \mu \mathrm{m}$, pallide brunnea, truncata, laevia, tenuitunicata; rami discreti, non-ramosi, dense appressi vel divergenti, cylindrici, 25-41 $\times 5-7 \mu \mathrm{m}, 5-10$-euseptati, ad septa modice constricti, pori septarum praediti, ad apicum recurvati. Conidiorum secessio schizolytica.

Conidiomata sporodochial, scattered, punctiform, pulvinate, dark brown to black, $100-300 \mu \mathrm{m}$ diameter. (FIG. 1). Mycelium mostly immersed in the substratum, composed of brown, smooth, thin-walled, septate, branched hyphae. Conidiophores semi-macronematous, mononematous, pale brown, smooth, thin-walled, unbranched, cylindrical, flexuous, 6-14 $\times 3-5 \mu \mathrm{m}$ (FIGs. 3, 4). Conidiogenous cells monoblastic, integrated, terminal, determinate, pale brown, smooth, thin-walled, non-proliferating (FIG. 4), giving rise to a single crop of conidia that mature synchronously. Conidia acrogenous, holoblastic, solitary, pale brown, chiroid, 30-45 $\times 12-21 \mu \mathrm{m}(\overline{\mathrm{x}}=39 \times$ $16 \mu \mathrm{m}, \mathrm{n}=30)$, euseptate, with $4-7(-8)$ arms vertically inserted on basal cells in different planes (FIGS. 2, 5-9); basal cells 3.5-6 × 3.5-5 $\mu \mathrm{m}$, pale brown, truncate, smooth, thin-walled (FIGS. 8, 9); arms discrete, unbranched, closely appressed to each other or divergent at maturity, cylindrical, 25-41 $\times 5-7$ $\mu \mathrm{m}, 5-10$-euseptate, slightly constricted at the septa, with conspicuous septal pores surrounded by marked pigmented rings 1-1.5 $\mu \mathrm{m}$ wide, appearing as dolipores in side view, mostly with a narrowed, recurved apical cell (FIGs. 5-9). Conidial secession schizolytic (FIGS. 6, 9).

Material examined. HONG KONG. Tai Po Kau Forest Stream, on submerged wood, 27 Jun 1996, K. D. Hyde WH 

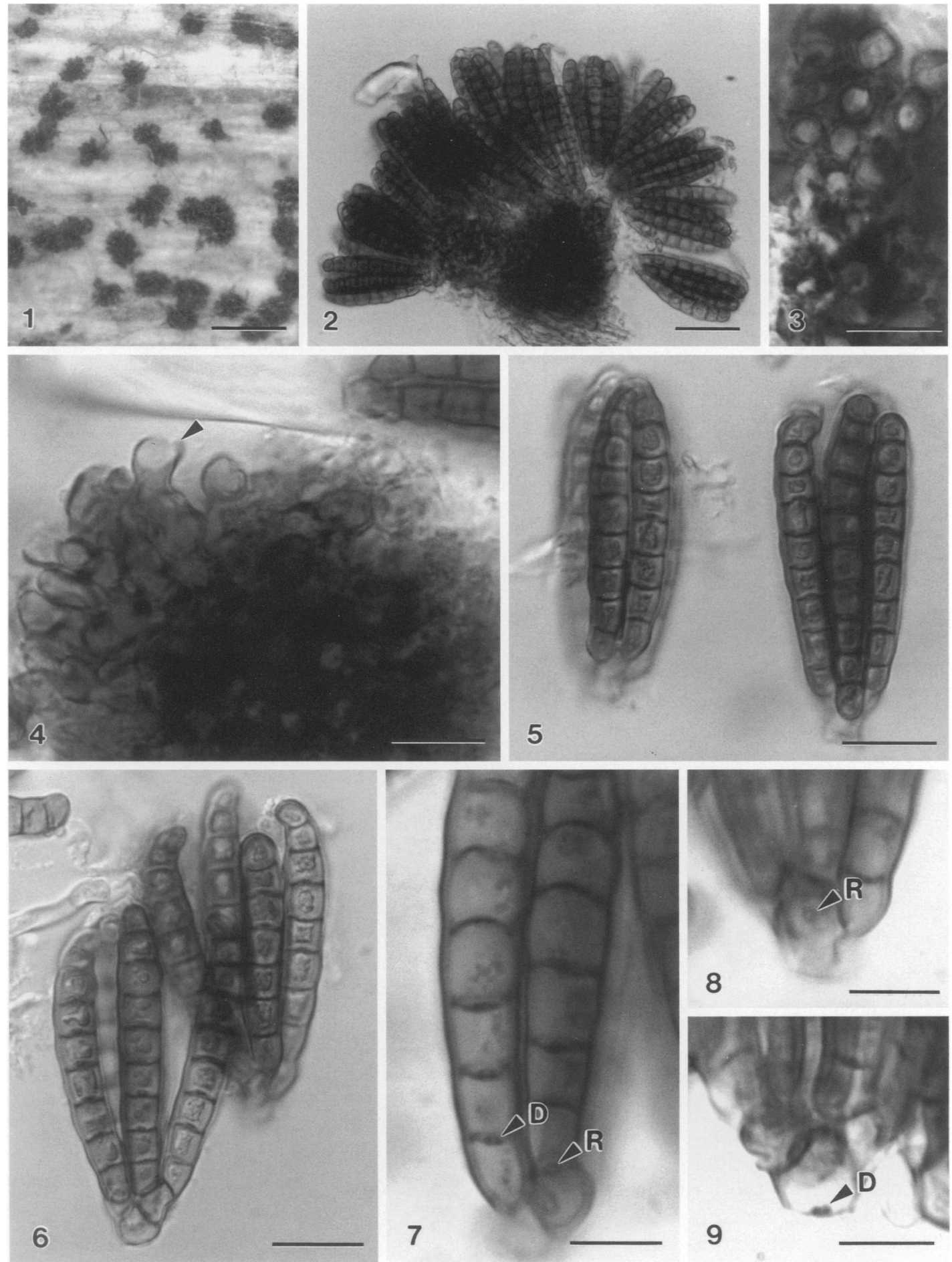

FIGS. 1-9. Dig. recurvum (from HOLOTYPE). 1. Colonies on woody substratum. 2. A sporodochium with conidial mass attached to conidiophores. 3. Conidiophores viewed from above, illustrating their circular lumina. 4. Mass of conidiophores. Note that the arrowed conidiophore is in side view. 5. Conidia with parallel euseptate arms vertically inserted on basal cells in different planes. Note that the arms of the conidium are closely appressed, while another is slightly divergent. 6 . Conidia with divergent arms. Note that the arms are recurved at the apex. 7. Closer view of the lower portion of a conidium. Note the conspicuous conidial septal pores surrounded by marked pigmented rings (R). The rings appear as dolipores (D) in side view. 8. Conidium at the basal portion illustrating the pigmented rings $(R)$ at the conidial septum. 9. Basal portion of a conidium, illustrating the pigmented ring of conidium delimiting septum. The ring appears as dolipore-like (D) in side view. Bars: $1=500 \mu \mathrm{m} ; 2=20 \mu \mathrm{m} ; 3-6=10 \mu \mathrm{m} ; 7-9=15 \mu \mathrm{m}$. 
TABLE I. Comparison of conidial morphology in species of Digitodesmium

\begin{tabular}{|c|c|c|c|}
\hline & & $\begin{array}{l}\text { Dig. recurvum } \\
\text { (This paper) }\end{array}$ & $\begin{array}{l}\text { Dig. elegans } \\
\text { (Kirk 1981) }\end{array}$ \\
\hline \multirow[t]{4}{*}{ Conidia } & Color & Pale brown & $-^{\mathrm{a}}$ \\
\hline & Diameter & 30-45 $\mu \mathrm{m}$ long, $12-21 \mu \mathrm{m}$ wide & $45-60 \mu \mathrm{m}$ long \\
\hline & Wall & Smooth & Smooth \\
\hline & Septal pores & $\begin{array}{l}\text { Conspicuous in all conidial de- } \\
\text { limiting and conidial septa, } \\
\text { surrounded by a marked ring } \\
\text { of pigmentation, visible in lat- } \\
\text { eral view as a dark brown disc } \\
1-1.5 \mu \mathrm{m} \text { wide }\end{array}$ & Inconspicuous \\
\hline \multirow[t]{3}{*}{ Basal cells } & Color & Pale brown & - \\
\hline & Diameter & $3.5-6 \mu \mathrm{m}$ high, $3.5-5 \mu \mathrm{m}$ wide & $2.5-5 \mu \mathrm{m}$ wide \\
\hline & Truncate & Yes & Yes \\
\hline \multirow[t]{6}{*}{ Conidial arms } & Number of arms & $(2-) 4-6(-7)$ & $(2-) 3-4(-6)$ \\
\hline & Diameter & 25-41 $\mu \mathrm{m}$ long 5-7 $\mu \mathrm{m}$ wide & $5-6 \mu \mathrm{m}$ diam \\
\hline & Apical cells & Mostly narrow and recurved & $\begin{array}{l}\text { Occasionally with a hyaline gelat- } \\
\text { inous cap }\end{array}$ \\
\hline & Constriction at the septa & Slightly & No \\
\hline & Branching & No & No \\
\hline & Number of septa & $6-10$ & $9-12$ \\
\hline
\end{tabular}

a Data not available.

300 H 98 [HOLOTYPE: HKU(M) 4552], 27 Dec 1997, W. H. Ho H 639 [HKU(M) 8739]; ibid. on submerged Machilus velutina wood bait, 29 Mar 1997, W. H. Ho H 383 [HKU(M) 6043].

Etymology. In reference to the recurved conidial arms.

Known distribution. Hong Kong.

Habitat. Saprobic on decaying wood in streams.

Teleomorph. Unknown.

Commentary. Our initial placement of Dig. recurvum was in the genus Dictyosporium, based on the similarity between our species and Dic. giganticum Goh \& K. D. Hyde, Dic. heptasporum (Garov.) Damon and Dic. subramanianii B. Sutton. These species have chiroid euseptate conidia with arms inserted in the basal cells in different planes, with most arms being terminated with a recurved hook (Goh and Hyde 1999). The conidial arms of Dig. recurvum become divergent at maturity, but those of the latter three species of Dictyosporium remain closely appressed (Goh and Hyde 1999). The conidial arms of Dic. heptasporum may become separate only under pressure (Goh and Hyde 1999). Dictyosporium cocophilum Bat. and Dic. micronesicum Matsush. also produce euseptate chiroid conidia with arms inserted in the basal cells in different planes, but the tips of the arms are straight and do not become divergent at maturity (Goh and Hyde 1999).

We also considered placing this species in genera such as Cheiromoniliophora S. S. Tzean \& J. L. Chen (1990), Cheiromycella Höhn (Sutton 1985), Dicrani- dion Harkn. (Peek and Solheim 1958), Pseudodictyosporium Matsush. (1971) and Ramiconidiifera B. Sutton, Carmaran \& A. I. Romero (1996) since all produce chiroid, euseptate conidia. The conidial arms in Cheiromoniliophora and Pseudodictyosporium, however, do not become divergent, while the conidiogenous cells of Cheiromycella, Dicranidion and Ramiconidiifera are able to proliferate. Our species agrees with the generic delineation of Digitodesmium (Kirk 1981) and thus it is assigned to this genus.

Digitodesmium recurvum differs from the type species, Dig. elegans, in having shorter conidia with arms which are recurved at the apex. In Dig. elegans, the conidial arms are straight and each arm possesses a hyaline gelatinous cap at the tip (Kirk 1981). Conidial morphology of the two species of Digitodesmium is compared in TABLE I.

In Dig. recurvum, a central pore surrounded by a marked ring of pigmentation are present in all conidial delimiting septa as well as in the conidial septa. The septal pores with rings of pigmentation appear as dolipores in lateral view. In the ascomycetes and their anamorphs, the septa are perforated by central, simple pores which can be resolved using transmission electron microscopy (Markham 1994). This central septal pore is more prominent in some thickwalled spores (e.g., Goos 1971, Ho et al 1999a) or cells of ascoma wall, such as the Munk pores (Jensen 1985) and the peridial pores (Cannon 1995) and can be resolved at light microscope level. 
Septal pores are not visible, and the pigmented rings are absent in the conidia of Dig. elegans (Kirk 1981). Pigmented rings surrounding the septal pores have been recorded in euseptate conidia [as in Canalisporium pallidum Goh, W. H. Ho \& K. D. Hyde (Goh et al 1998a)], distoseptate conidia [as in Pyricularia peruamazonica Matsush. (Matsushima 1993)] or conidia with distosepta and eusepta [as in Janetia curviapicis Goh \& K. D. Hyde (Goh and Hyde 1996)]. This pigmented ring can be a generic feature (e.g., all species of Canalisporium possess this structure; Goh et al 1998a), or a specific feature (e.g., only some species of Bactrodesmium possess this structure; Ellis 1971).

Digitodesmium is characterized by chiroid, euseptate conidia produced on sporodochia (Kirk 1981). Morphologically, this genus is similar to Cheiromyces Berk. \& Curtis, except that the latter produce distoseptate conidia (Sutton 1985). Sutton (1985) observed that cells in the conidia of Digitodesmium have two features characteristic of distosepta, i.e., (i) the lumina are reduced, and (ii) the septal walls do not fully abut onto the periclinal walls. Based on this type of septation, Sutton (1985) commented that Digitodesmium should possibly be synonymised with Cheiromyces, which produces chiroid distoseptate conidia, but he hesitated to do so.

In Dig. recurvum, the conidial cells also have reduced lumina due to the thickening of the cell walls. Although reduced lumina or thickened cell walls are commonly found in distoseptate conidia, these characteristics are not restricted to distoseptate conidia. The conidia of Acrodictys M. B. Ellis (1971), Bactrodesmium Cooke (Ellis 1959), Canalisporium Nawawi et Kuthub. (Goh et al 1998a) and Cancellidium Tubaki (1975) have reduced cell lumina, but they are considered euseptate. Furthermore, the septal walls of mature thick-walled conidia, such as those of $A c$ rodictys, Bactrodesmium and Canalisporium, also appear to be discontinuous with the periclinal wall when observed at $\times 1000$ magnification using immersion oil (Ho pers obs). These septal walls and periclinal walls are clearly continuous in the immature, thin-walled conidia of these species. The apparent discontinuity in the walls of mature conidia is due to the artifacts brought about by light refracting through the thickened wall. Possibly, Sutton's (1985) observation on the discontinuity of the septal walls and periclinal walls may also have been the result of artifacts. His observation on the reduced conidial cell lumina do not warrant consideration of such conidia to be distoseptate. For these reasons, we retain the genus Digitodesmium.

\section{ACKNOWLEDGMENTS}

We thank Dr. T. K. Goh of The University of Hong Kong for his valuable comments on the manuscript. The staff in the Photographic Unit of the Faculty of Science, The University of Hong Kong are thanked for photographic assistance. Thanks are extended to Ms. Helen Y. M. Leung for technical assistance. W. H. Ho thanks The University of Hong Kong for the award of a postgraduate studentship.

\section{LITERATURE CITED}

Cannon PF. 1995. Studies on fungi with isthmoid ascospores: the genus Vialaea, with the description of the new family Vialaeaceae. Mycol Res 99:367-373.

Ellis MB. 1959. Clasterosporium and some allied Dematiaceae-Phragmosporae. I. Mycol Paper 72:1-89.

- ed. 1971. Dematiaceous hyphomycetes. Kew, England: Commonwealth Mycological Institute. 608 p.

Goh TK, Ho WH, Hyde KD, Whitton SR, Umali TE. 1998a. New records and species of Canalisporium (Hyphomycetes), with a revision of the genus. Can J Bot 76:142152.

- Hyde KD. 1996. Janetia curviapicis, a new species, and an emended description of the genus. Mycologia 88:1014-1021.

- 1999. A revision of the genus Dictyosporium, with descriptions of three new species. Fung Divers 2: 65-100.

,-- , Ho WH. 1998b. Aquaphila albicans gen. et sp. nov. (Hyphomycetes) from submerged wood in the tropics. Mycol Res 102:587-592.

Goos RD. 1971. Listeromycetes insignis refound. Mycologia 63:213-218.

Ho WH, Goh TK, Hyde KD, Hodgkiss, IJ. 1999a. Studies of conidial anatomy and conidiogenesis in Sporoschisma nigroseptatum using light and electron microscopy. Can J Bot 76:1614-1623.

—, Hyde KD, Hodgkiss, IJ. 1997. Ascomycetes from tropical freshwater habitats: the genus Savoryella, with two new species. Mycol Res 101:803-809.

,--1 - 1999b. Ascal ultrastructural study in Annulatascus hongkongensis, a freshwater ascomycete. Mycologia 91:885-892.

,$--1999 \mathrm{c}$. Ultrastructure of Annulatascus aquaticus sp. nov., a freshwater ascomycetes on submerged wood from Hong Kong. Fung Divers 2:119128.

Hyde KD, Ho WH, Tsui KM. 1998. The genera Aniptodera, Halosarpheia, Nais and Phaeonectriella from freshwater. Mycoscience (In press).

Jensen JD. 1985. Peridial anatomy and Pyrenomycete taxonomy. Mycologia 77:688-701.

Kirk PM. 1981. New or interesting microfungi. Trans Br Mycol Soc 77:279-297.

Markham P. 1994. Occlusions of septal pores in filamentous fungi. Mycol Res 98:1089-1106.

Matsushima T. 1971. Microfungi of the Solomon Islands and Papua-New Guinea. Kobe, Japan: Publ by author. 78 p 169 pl. 
1993. Matsushima mycological memoirs. No. 7. Kobe, Japan: Publ by author. 75 p.

Peek CA, Solheim WG. 1958. The hyphomycetous genera of H. W. Harkness and the ascomycetous genus Cleistosoma Harkn. Mycologia 50:844-861.

Sutton BC. 1985. Notes on some deuteromycete genera with cheiroid or digitate brown conidia. Proc Indian Acad Sci (Pl Sci) 94:229-244.
, Carmaran CC, Romero AI. 1996. Ramiconidiifera, a new genus of hyphomycetes with cheiroid conidia from Argentina. Mycol Res 100:1337-1340.

Tubaki K. 1975. Notes on the Japanese hyphomycetes. VII. Cancellidium, a new hyphomycetes genus. Trans Mycol Soc Japan 16:357-360.

Tzean SS, Chen JL. 1990. Cheiromoniliophora elegans gen. et sp. nov. (Hyphomycetes). Mycol Res 94:424-427. 